\title{
Cross-talks of tumor and myeloid cells regulate the therapeutic responses to chemotherapy by modulating innate immune responses
}

Masahisa Jinushi ${ }^{{ }^{*}}$, Muhammad Baghdadi ${ }^{1}$, Hideo Yagita ${ }^{2}$

From Society for Immunotherapy of Cancer 28th Annual Meeting

National Harbor, MD, USA. 8-10 November 2013

Tumor-associated myeloid cells play a critical role in supporting tumor progression and metastasis. However, molecular mechanisms by which tumor cells interact with myeloid cells to modify therapeutic responses to anticancer treatments remain largely unknown. We identified several key factors affecting antitumor effects of chemotherapy by manipulating the modes of interaction between tumor cells and myeloid cells within

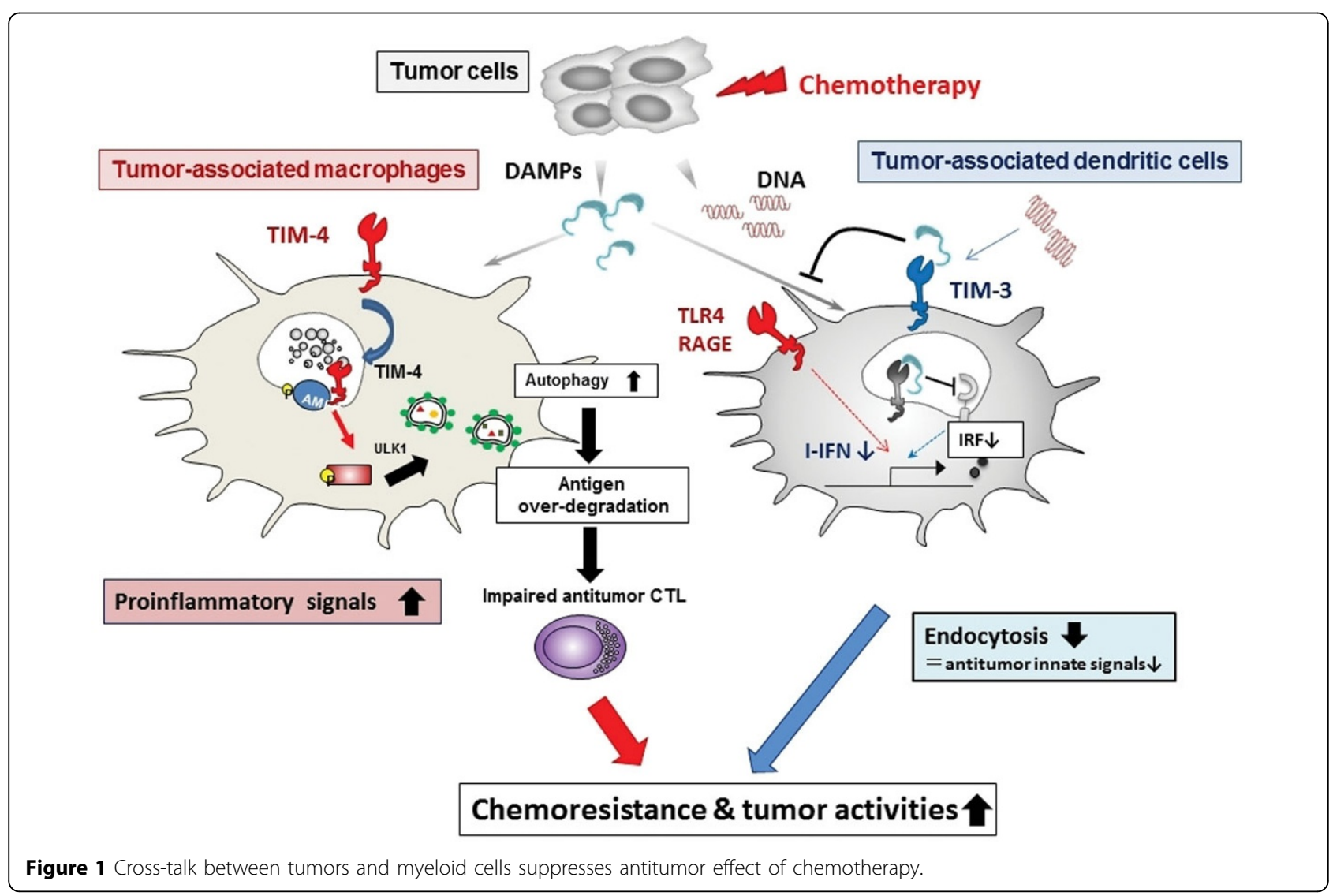

Institute for Genetic Medicine, Hokkaido University, Sapporo, Japan

Full list of author information is available at the end of the article 
tumor microenvironments. Tumor-derived factors such as VEGF-A and arginase-I upregulate TIM-3 on dendritic cells. TIM-3 interacts with HMGB1 released from chemotherapy-treated tumor cells, and suppresses innate pattern recognition signals mediated by nucleic acids from dying tumor cells. The inhibition of TIM-3 augments antitumor effects of cytotoxic chemotherapy against established tumors. Moreover, danger-associated molecular patterns (DAMPs) released from chemotherapy-damaged tumor cells induced TIM- 4 on TAMs recruited from bone marrow-derived precursors. TIM-4 directly interacted with AMPK- $\alpha 1$ at phagosome and activated autophagy-mediated lysosomal degradation of ingested tumors, leading to reduced antigen presentation and impaired CTL responses. Consistently, blockade of the TIM-4/AMPK- $\alpha 1 /$ autophagy pathway augmented antitumor effect of chemotherapeutics by enhancing tumor-specific CTL responses. Taken together, our findings provide new evidences that targeting of key factors regulating interplay between tumor cells and myeloid cells provides new therapeutic strategy to eradicate chemoresistant tumors.

\footnotetext{
Authors' details

${ }^{1}$ Institute for Genetic Medicine, Hokkaido University, Sapporo, Japan.

${ }^{2}$ Department of Immunology, Juntendo University, Tokyo, Japan.
}

Published: 7 November 2013

doi:10.1186/2051-1426-1-S1-016

Cite this article as: Jinushi et al:: Cross-talks of tumor and myeloid cells regulate the therapeutic responses to chemotherapy by modulating innate immune responses. Journal for ImmunoTherapy of Cancer 2013 1(Suppl 1):016

\section{Submit your next manuscript to BioMed Central} and take full advantage of:

- Convenient online submission

- Thorough peer review

- No space constraints or color figure charges

- Immediate publication on acceptance

- Inclusion in PubMed, CAS, Scopus and Google Scholar

- Research which is freely available for redistribution

Submit your manuscript at www.biomedcentral.com/submit
C Biomed Central 